\title{
Komparativna istraživanja javne uprave $u$ brvatskim znanstvenim časopisima od 2009. do 2015.
}

\author{
Ivan Lehpamer* \\ UDK 35:340.5(497.5)(05) \\ Review scientific paper / pregledni znanstveni rad \\ Received / primljeno: 18.11.2016. \\ Accepted/prihvaćeno: 15. 3.2017.
}

Difuzija modela upravnih reformi u globaliziranom okolišu 21. stoljeća sve je manje ovisna o geografskim i kulturološkim barijerama. Stoga komparacija i kontekstualizacija upravnih fenomena treba postati esencijalni dio upravne znanosti. Komparativna istraživanja ogledalo su prilika u raznim upravnim sustavima i mogući su orijentir za primjenu upravnih modela u budućnosti. Značenje komparativne javne uprave i doseg primjene komparativne metode istraživanja u Hrvatskoj autor istražuje metodom analize sadržaja znanstvenih članaka, a naglasak je na komparativnim člancima koji javnu upravu tematiziraju u najmanje dvije države, osim Republike Hrvatske. Pregledom 151 časopisa iz područja društvenih znanosti locirano je 13 komparativnih članaka i 40 studija slučaja, objavljenih od 2009. do 2015. Istraživanje je počelo hipotezom da hrvatski znanstveni časopisi imaju važan komparativni segment koji pri-

* Ivan Lehpamer, stručni specijalist javne uprave, Zagreb (Graduated Expert Specialist of Public Administration, Zagreb, Croatia, e-mail: IvanLehpamer@gmail.com). 
donosi razvoju discipline komparativne javne uprave. Autor djelomično odbacuje početnu hipotezu i utvrđuje da je postojeći komparativni segment hrvatskih znanstvenih časopisa nedostatan, međutim, iznimno komparativno vrijedan.

Ključne riječi: komparativna javna uprava, znanstveni časopisi, komparativna metoda istraživanja, analiza sadržaja

\section{Uvod}

U suvremenom globaliziranom, digitaliziranom i visoko umreženom ambijentu komparativna perspektiva neizostavan je aspekt u proučavanju i analizi sustava javne uprave i modela reformi javnog sektora. Sustav javne uprave traži odgovarajuće institucionalne, regulativne, funkcionalne, tehnološke i kulturološke okvire za efektivno, efikasno i ekonomično ostvarivanje pravnim propisima i strateškim dokumentima definiranih zadaća i ciljeva. Rezultati komparativnih analiza omogućuju prepoznavanje dobrih praksi i kvalitetnih reformskih inovacija u sustavima javnog upravljanja, a to može smanjiti neželjene implikacije u prenošenju i implementaciji reformskih modela. Usporedbom, analizom i kontekstualizacijom upravnih pojava komparativna javna uprava pridonosi njihovoj učinkovitoj primjeni u različitim društvenim, političkim, pravnim i upravnim okolišima. Komparativna javna uprava podatkovnom kumulacijom pridonosi boljem razumijevanju funkcioniranja upravnih fenomena i javne uprave, a njihova komparativna istraživanja svojevrsno su ogledalo prilika u javnoj upravi i potencijalni orijentir za praktičnu primjenu.

Svrha ovog rada jest prikaz suvremenih trendova u komparativnim istraživanjima javne uprave u razdoblju od 2009. do 2015. kroz dubinsku analizu sadržaja hrvatskih znanstvenih časopisa iz područja društvenih znanost. ${ }^{1}$ Autor metodom analize sadržaja znanstvenih članaka utvrđuje postojanje komparativnog segmenta u objavljenim člancima, a rezultatima istraživa-

\footnotetext{
${ }^{1}$ Prvobitna intencija provedenog istraživanja bila je usporedba dosega primjene komparativne metode istraživanja u znanstvenim časopisima objavljenima u Hrvatskoj i u zemljama bliskog okružja: Bosni i Hercegovini, Sloveniji i Srbiji. Međutim, takav komparativni prikaz nije bio moguć zbog (1) nedostatnog komparativnog segmenta analiziranih znanstvenih časopisa (bosanskohercegovački časopisi Uprava i Moderna uprava te slovenski časopis Međunarodna revija za javno upravo), (2) prestanka izlaženja pojedinih edicija (srpski časopis Agenda) i (3) ograničenja tematske strukture časopisa (slovenski časopis Lex Localis).
} 
nja prikazuje doseg i značenje komparativne metode istraživanja u objavljenim znanstvenim člancima. Svojevrsni metodološki uzor predstavlja rad A New Look at Comparative Public Administration: Trends in Research and an Agenda for the Future ${ }^{2}$ (Machado \& Martell, 2011).

Istraživanje započinje hipotezom da hrvatski znanstveni časopisi imaju važan komparativni segment koji pridonosi razvoju discipline komparativne javne uprave i njezinu pozicioniranju unutar same upravne znanosti. Metodom analize sadržaja znanstvenih članaka autor provjerava svoju hipotezu te utvrđuje stanje primjene komparativne metode istraživanja javne uprave u hrvatskim znanstvenim časopisima. Početna faza istraživanja obuhvaća sustavni pregled 151 časopisa iz područja društvenih znanosti objavljenih na portalu znanstvenih časopisa Republike Hrvatske - www. hrcak.srce.hr - te lociranje i klasifikaciju znanstvenih radova koji tematiziraju javnu upravu metodom studije slučaja ili komparativnim prikazom u najmanje dvije države, osim Republike Hrvatske, koji su objavljeni od 2009. do $2015 .^{3}$ Analizom su obuhvaćeni i radovi stranih autora koji pišu o vlastitoj zemlji, a čiji su radovi objavljeni u hrvatskim znanstvenim časopisima. Oni su također značajni za razvoj komparativnog usmjerenja pojedinog časopisa. Članci koji odgovaraju utvrđenim kriterijima klasificirani su s obzirom na vrstu članka, vrstu istraživanja, predmet istraživanja, zemlje koje su obuhvaćene komparativnim prikazom i s obzirom na metodu istraživanja.

U prvom dijelu rada autor obrazlaže značenje komparativne javne uprave i komparativne metode istraživanja javne uprave kroz povijesni presjek razvoja navedene discipline i metode istraživanja. Središnji dio rada sadr-

${ }^{2}$ U navedenom radu autori Jason Machado i Christine Martell predstavljaju rezultate analize sadržaja 151 komparativnog članka objavljenog u 28 znanstvenih časopisa od 2000. do 2009. Šesteročlani istraživački tim klasificirao je članke prema: vrsti istraživanja, primjeni teorije, predmetu istraživanja, jedinici analize i metodologiji članka. Upravna reforma i odgovornost/praćenje učinka/evaluacija najzastupljenije su tematske skupine u promatranom razdoblju. Europa i Velika Britanija te SAD čine geografski fokus 77\% odnosno 25\% svih objavljenih radova. Kvalitativna istraživanja i ponovno korištenje postojećih podataka najzastupljeniji su metodološki odabiri autora. Autori zaključno predlažu primjenu komparativne metode istraživanja u svim područjima upravne znanosti, širenje geografskog fokusa komparativnih istraživanja na Afriku i Južnu Ameriku te širu primjenu kulturološkog okvira istraživanja u komparativnim radovima.

${ }^{3}$ Istraživanje suvremenih trendova u komparativnim istraživanjima javne uprave usredotočeno je na razdoblje od 2009. do 2015. zbog olakšane dostupnosti znanstvenih i stručnih publikacija putem portala www.hrcak.srce.hr te na istraživanja provedena u periodu do 2009. koja su metodološki i tematski srodna, iako samo indirektno usporediva s ovim istraživanjem. 
Žava opis istraživanja i svrhu rada te prikaz rezultata provedenog istraživanja. Zaključno, autor daje osvrt na početnu hipotezu te konačan prikaz suvremenih trendova u komparativnim istraživanjima javne uprave $\mathrm{u} \mathrm{hr}$ vatskim znanstvenim časopisima od 2009. do 2015.

\section{Značenje komparativne javne uprave}

Grana upravne znanosti koja se bavi komparativnom analizom upravnih procesa i institucija naziva se komparativnom javnom upravom. Značenje komparativne javne uprave proizlazi iz mogućnosti usporedbe i analize upravnih struktura i njihova funkcioniranja u različitim društvenim okolišima. Iako zasadi komparativne javne uprave sežu u doba stare Grčke i velikih atenskih filozofa Aristotela i Platona, intenzivniji razvoj te grane upravne znanosti datira u 1950. u Sjedinjenim Američkim Državama (Lalić Novak, 2015, str. 11).

Nakon svojevrsne inauguracije komparativne javne uprave 1952. na američkom Sveučilištu Princeton, važnost komparativnih istraživanja javne uprave prepoznao je i znanstveni časopis American Political Science Review koji je 1963. dodao bibliografsku sekciju pod nazivom Comparative Public Administration. Sam časopis premijerno je publiciran 1906., a izdaje ga organizacija American Political Science Association. Zamah disciplini daje i Grupa za komparativnu upravu (The Comparative Public Administration Group) osnovana pri Američkom društvu za javnu upravu (American Society for Public Administration) koje od 1985. dodjeljuje i nagradu za životno akademsko postignuće na području komparativne javne uprave u čast jednog od začetnika komparativne javne uprave Freda W. Riggsa. Profesor političkih znanosti F. W. Riggs i Grupa za komparativnu upravu, kojoj je bio na čelu, najzaslužniji su za pokret komparativne javne uprave i stvaranje te discipline znanosti o upravi (Rathod, 2007, str. 9).

Komparativna javna uprava ubrzano se razvijala tijekom 60 -ih i 70 -ih godina 20. stoljeća, kao svojevrsna reakcija na tradicionalnu literaturu o javnoj upravi koja je bila snažno usmjerena na upravne sustave zapadnoeuropskih zemalja i SAD-a. Razvoj discipline posebice je bio značajan u SAD-u, predvodniku u borbi protiv komunizma te najvećem donatoru financijske pomoći zemljama u razvoju. Znatnu ulogu u razvoju komparativne javne uprave imale su i svjetske financijske organizacije koje su u zapadnom upravnom modelu pronašle odgovor za nedostatne upravne kapacitete zemalja trećeg svijeta i zemalja u razvoju. Tijekom 80 -ih došlo je do zastoja u 
razvoju discipline koji se povezuje s jačanjem novog javnog menadžmenta i primjenom tržišnih metoda u javnom sektoru. 1990-ih dolazi do promjene dotadašnjeg političkog režima u mnogim zemljama svijeta, a ponajprije u istočnoeuropskim zemljama, što je potaknulo ponovno oživljavanje komparativne javne uprave (Machado \& Martell, 2011, str. 822).

Komparativna javna uprava kao znanstvena disciplina znanosti o javnoj upravi izučava se na mnogobrojnim visokoškolskim obrazovnim ustanovama u Hrvatskoj, što pridonosi daljnjem razvoju te discipline. Izborni kolegij Komparativna javna uprava sastavni je dio izvedbenog nastavnog plana V. godine integriranog Pravnog studija i obvezni kolegij I. godine Specijalističkog diplomskog stručnog studija javne uprave na Pravnom fakultetu Sveučilišta u Zagrebu. Komparativna javna uprava izvodi se kao obvezni kolegij i na I. godini Specijalističkog diplomskog stručnog studija javne uprave na Pravnom fakultetu Sveučilišta Josipa Jurja Strossmayera u Osijeku. Komparativna metoda u proučavanju javne uprave izučava se i na preddiplomskoj razini kroz kolegij Temeljni komparativni upravni sustavi u V. semestru preddiplomskog stručnog studija javne uprave Pravnog fakulteta Sveučilišta u Zagrebu. Izučavanje komparativne javne uprave kroz specijalizirane kolegije pridonosi njezinoj profilaciji kao samostalne discipline upravne znanosti, međutim znanstveno-istraživački rad i ekstenzivna primjena komparativne metode u proučavanju javne uprave najjače pozicionira komparativnu javnu upravu kao društveno relevantnu znanstvenu disciplinu.

Komparativna javna uprava može biti obogaćena samo kritičkim, analitičkim i interkulturalnim istraživanjima temeljenim na objektivnim podacima o različitim zemljama svijeta. Interkulturna istraživanja esencijalni su dio komparativne javne uprave i upravo ona snažno pozicioniraju tu disciplinu unutar same upravne znanosti. Znanost o javnoj upravi u suvremenom globaliziranom i umreženom svijetu treba biti komparativna, a važnost toga naglasio je Dwight Waldo rekavši kako u nastojanju da javna uprava postane znanstvena disciplina njezina objašnjenja moraju biti komparativno racionalna (Rathod, 2007, str. 8).

U stvaranju i kumuliranju teoretskog i primjenjivog znanja komparativna javna uprava ima neupitno značenje. No usprkos neupitnoj vrijednosti i značenju discipline, njezina efikasnost podvrgnuta je skupu kritika. Manjak konsenzusa oko definicije same discipline, nedostatna integracija s javnom upravom općenito i nedostatak teorije samo su neke od njih (Machado \& Martell, 2011, str. 822). 


\subsection{Komparativna metoda istraživanja javne uprave}

Poredba, usporedba ili komparacija sinonimi su koji predstavljaju srž široko prihvaćene i rasprostranjene znanstvene metode istraživanja, kako u društvenim znanostima tako i u istraživanjima javne uprave. Komparativna metoda istraživanja omogućuje lociranje sličnosti, usporedbu i prepoznavanje različitosti, te kontekstualizaciju informacija, a to pomaže $\mathrm{u}$ interpretaciji i valorizaciji uspoređenih podataka. Metoda usporedbe pruža uvid u sličnosti i različitosti javne uprave i njezinih dijelova u dvije ili više uspoređenih država prikazom sadašnjeg stanja ili vremenskog presjeka razvoja uspoređenih upravnih sustava. Komparacija pritom može obuhvatiti: upravni sustav kao cjelinu, službenički sustav, teritorijalni ustroj, funkcije javne uprave i slično.

Uspoređivanje upravnih obilježja seže još u razdoblje stare Grčke i velikih atenskih filozofa (Lalić Novak, 2015, str. 10). Savjetnici vladara i ondašnja javnost bilježili su svoja opažanja o radu vladajućih, pa su tako njihova opažanja sadržana i u drevnim spisima poput Kautilyanove Arthashastre u Indiji, Biblije i Aristotelove Politike te u djelu talijanskog političara i književnika Machiavellija Vladar. No, do većeg interes za sustave upravljanja vladinim poslovima došlo je tek s procvatom kameralizma u Njemačkoj, krajem 17. i početkom 18. stoljeća (Heady, 2006, str. 61).

Krajem 19. stoljeća Woodrow Wilson i Frank Goodnow, pioniri u istraživanjima američke javne uprave, vukli su paralele s europskim suvremenicima. Američkog 28. predsjednika Thomasa Woodrowa Wilsona nazivaju i »prvim komparatistom « zbog značenja njegova eseja The study of administration iz 1884. Mogućnost analiziranja anatomije stranih vlada bez opasnosti od prenošenja negativnih efekata i ugrožavanja vlastita sustava značaj je upravo komparativne javne uprave, navodi Wilson. Wilson je prvi usporedio američki sustav vladavine s kabinetskim sustavom Velike Britanije (Rathod, 2007, str. 24).

Europski i američki modeli javne uprave proučavali su i znanstvenici iz tzv. »trećeg svijeta«, a neki od razloga su kolonijalizacija i uspostavljanje upravnih sustava u trećim zemljama od strane kolonizatora; ubrzavanje protoka informacija i mogućnosti razmjene i usporedbe informacija o upravnim sustavima te tzv. »domino efekt« ljudskog razvoja odnosno poticanje razvoja kroz prihvaćanje institucionalnih i upravnih modela od međunarodnih organizacija (Otenyo \& Lind, 2006).

Kraj II. svjetskog rata i pojava globalnih međunarodnih organizacija značajno su utjecali na jačanje komparativne metode u javnoj upravi te tako 
komparativna istraživanja javne uprave doživljavaju svoj procvat neposredno nakon rata, 1950-ih godina. Važnost komparativne metode $\mathrm{u}$ istraživanjima javne uprave naglasio je i Fred W. Riggs: »Sve političke znanosti i znanstveno razumijevanje javne uprave treba biti komparativno« ( $\mathrm{He}-$ ady, 2006, str. 72-73).

Nema potpunog razumijevanja društvenih i upravnih struktura bilo koje zemlje ako ih ne možemo usporediti sa znanjima o drugim društvenim i upravnim sustavima. Osnovnu strukturu institucija neke države i međusobnu povezanost njezinih strukturnih elemenata moguće je analizirati i bez komparativnog pristupa, no nije moguće prepoznati jesu li te institucije efikasne, demokratske ili etične. Primjerice, demokratičnost, efikasnost i etičnost ne mogu biti i nisu apsolutne vrijednosti i nemoguće je osmisliti organizaciju ili strukturu koja bi bila apsolutno demokratična, efikasna ili etična. Stoga usporedba navedenih vrijednosti jedina omogućava donošenje zaključaka o efikasnosti, etičnosti i demokratičnosti sustava koji upravljaju životima svih nas. Njemački, francuski, kineski, indijski ili hrvatski upravni sustav može biti ocijenjen više ili manje efikasnim u usporedbi s nekim od njih nego s nekom hipotetskom i idealnom situacijom koja u praksi ne može egzistirati (Chandler, 2014.). Iz navedenoga proizlazi i pravo značenje komparativne metode istraživanja u javnoj upravi i značenje komparativne javne uprave uopće.

\subsection{Predmet i svrha komparativnog istraživanja javne uprave}

Jedinica analize u komparativnim istraživanjima javne uprave je upravni sustav, a fokus može biti usmjeren na upravni sustav u cjelini ili na njegov dio. Predmet istraživanja može biti: okoliš upravnog sustava, upravni sustav kao cjelina, formalne strukture upravnog sustava, podjela rada, specijalizacija, decentralizacija, kontrolni mehanizmi, procedure i slično. Neformalne organizacijske strukture koje egzistiraju unutar upravnog sustava, a odnose se na odnose među pojedincima, na motivaciju, neformalnu komunikaciju i vodstvo, također mogu biti tematski fokus komparativnih istraživanja. (Lalić Novak, 2015, str. 15).

Javna uprava u svojoj je srži komparativna, a usporedba može biti orijentirana na različite upravne organizacije, na različite države ili pak na različite teritorijalne organizacijske jedinice određene države. Razvoj upravnog sustava može se promatrati i u različitim vremenskim točkama, a njihovom komparacijom istraživač dobiva razvojnu sliku nekog upravnog susta- 
va, te mogućnost komparativnog pregleda prošlog i sadašnjeg upravnog stanja (Rathod, 2007, str. 2).

U procesu izgradnje teorije i razmjene ideja komparacija ima imperativno značenje. Istraživači pridaju određene karakteristike pojmovima i konceptima koji su slični jedan drugome, stoga predmet komparativnog istraživanja mogu biti službenički sustavi, struktura i funkcije upravnih organizacija, reforme javnog sektora, pravni okvir sustava javne uprave i slično. Uspoređeni pojmovi, koncepti ili pak aspekti javnih uprava se kontekstualiziraju, klasificiraju, analiziraju i interpretiraju, a to čini temelj za predviđanje ishoda kompariranih koncepata u drugim zemljama. Potonje i jest svrha komparativnog istraživanja javne uprave (Lalić Novak, 2015, str. 15).

\section{Suvremeni trendovi u komparativnim istraživanjima javne uprave u hrvatskim znanstvenim časopisima}

\subsection{Opis istraživanja i svrha rada}

Časopisi i objavljeni članci predstavljaju tekuće spoznaje, ideje i promišljanja o predmetu proučavanja komparativne javne uprave. Stoga je proučavanje znanstvenih radova u znanstvenim časopisima važna istraživačka metoda u upravnoj znanosti koja omogućava opći pregled stanja u javnoj upravi određene države te smjer trendova u istraživanjima javne uprave (Lopižić, 2013, str. 401). Istraživanje suvremenih trendova u komparativnim radovima javne uprave u Hrvatskoj od 2009. do 2015. započinje lociranjem članaka koji tematiku javne uprave obrađuju metodom studije slučaja ili komparativnim prikazom u najmanje dvije države, osim Republike Hrvatske, koji su objavljeni u razdoblju od 2009. do 2015. u časopisima iz područja društvenih znanosti. Osim zemalja, istraživanjem su obuhvaćene i teritorijalne jedinice (okruzi, županije, savezne države, pokrajine i gradovi). Članci koji obrađuju pojedine javne politike ili Republiku Hrvatsku po bilo kojem kriteriju nisu dio ovog istraživanja.

Prva faza istraživanja obuhvaća sustavni pregled i klasifikaciju 151 časopisa iz područja društvenih znanosti objavljenih na portalu znanstvenih časopisa Republike Hrvatske - www.hrcak.srce.hr. Analizom sadržaja objavljenih znanstvenih radova identificirani su članci koji odgovaraju definiranim kriterijima. Pregledom znanstvenih časopisa iz područja druš- 
tvenih znanosti utvrđen je konačni broj od $13^{4}$ komparativnih članka, u 2 znanstvena časopisa: Anali Hrvatskog politološkog društva ${ }^{5}$ te Hrvatska i komparativna javna uprava. ${ }^{6}$ Disperzijom fokusa istraživanja suvremenih trendova u komparativnim istraživanjima javne uprave i na studije slučaja broj komparativnih članaka doseže $53 .{ }^{7}$ Iako se studije slučaja ne smatraju komparativnim radovima, one imaju značajnu komparativnu vrijednost sadržavaju li upravne koncepte koji su primjenjivi i na druge zemlje. Usporedna istraživanja javne uprave gotovo su u potpunosti zatvorena u časopisu Hrvatska i komparativna javna uprava, osim dva članka u časopisu Anali hrvatskog politološkog društva, što je i razlog značajnog disbalansa u broju članaka koji čine podlogu ovog istraživanja.

Članci koji su udovoljili tematskom kriteriju podvrgnuti su dubinskom pregledu sadržaja te klasificirani i kategorizirani s obzirom na: vrstu članka (izvorni znanstveni članak, prethodno priopćenje, pregledni članak i stručni članak); vrstu istraživanja (deskriptivno, kauzalno i eksploratorno istraživanje); predmet istraživanja, zemlje koje su obuhvaćene komparativnim prikazom te s obzirom na metodu istraživanja kojom se autor koristio (kvalitativne ili kvantitativne metode istraživanja).

Svrha ovog rada jest prikaz suvremenih istraživačkih trendova u području komparativne javne uprave u Hrvatskoj od 2009. do 2015. i ispitivanje dosega komparativne istraživačke metode u hrvatskim znanstvenim časopisima te utvrđivanje stanja discipline komparativne javne uprave. $U$ fokusu istraživanja suvremenih trendova obuhvaćeni su radovi i hrvatskih i stranih autora prvenstveno zbog nove koncepcije časopisa Hrvatska i komparativna javna uprava koju karakterizira snažno uključivanje u me-

${ }^{4}$ Đurman \& Musa (2014), Halligan (2012), Herak (2011), Ivanišević (2009), Koprić (2009), Koprić (2012), Lazin (2014), Marčetić \& Giljević (2010), Marčetić (2015), Mikulić (2009), Pavić (2010), Seidel \& Vakkuri (2015), Wollmann (2011) - za detalje o radovima v. Prilog 1.

${ }^{5}$ Časopis Anali Hrvatskog politološkog društva od 2004. izdaje Hrvatsko politološko društvo u formi godišnjaka, a objavljuje radove iz područja političkih znanosti, prava te drugih srodnih disciplina. Glavni urednik časopisa je izv. prof. dr. sc. Enes Kulenović s Fakulteta političkih znanosti Sveučilišta u Zagrebu.

${ }^{6}$ Časopis Hrvatska i komparativna javna uprava, prvi i jedini specijalizirani časopis za teoriju i praksu javne uprave u Hrvatskoj, izlazi četiri puta godišnje, a utemeljen je 1999. Glavni urednik časopisa je prof. dr. sc. Ivan Koprić, predsjednik Instituta za javnu upravu te redoviti profesor i predstojnik Katedre za upravnu znanost Pravnog fakulteta u Zagrebu. 2011. godine prihvaćen je novi naziv i koncept časopisa Hrvatska i komparativna javna uprava, koji je do tada izlazio pod nazivom Hrvatska javna uprava.

7 Popis analiziranih članaka sadržan je u prilogu 1 ovog rada. 
đunarodnu znanstvenu razmjenu, što je rezultiralo i snažnom prisutnošću stranih autora u navedenom časopisu. ${ }^{8}$

\subsection{Razine analize i opseg komparativnih istraživanja}

Komparativna javna uprava može se izučavati na tri analitičke razine: na makrorazini, srednjoj odnosno mezzo i mikrorazini. Usporedba upravnih sustava kao cjelina u njihovu ekološkom kontekstu jest istraživanje na makrorazini. Istraživanje na makrorazini komparativnim prikazom obuhvaćalo bi upravne sustave Njemačke i Francuske, a sadržavalo opsežnu analizu najvažnijih aspekata i dijelova obaju upravnih sustava. Mezzostudije, na sredini raspona između makro i mikrorazine komparativnog istraživanja, fokusirane su na neke važne dijelove upravnog sustava koji su obuhvatni u veličini i djelokrugu poslova. Primjerice, usporedba lokalne samouprave u dvije ili više različitih država. Upravo je mezzorazina analize najčešće prisutna u analiziranim radovima, u gotovo $70 \%$ objavljenih komparativnih članaka. Pojedinačne organizacije ili drugi manji dio upravnog sustava predmet su izučavanja mikrostudija. Zapošljavanje, obrazovanje i osposobljavanje upravnih službenika u dvije ili više jedinica analize fokus su mikrostudija (Basu, 2004, str. 393).

Komparativna studija javne uprave može obuhvatiti: (1) međuinstitucionalnu analizu s fokusom na upravnoj organizaciji kao cjelini ili nekom njezinu dijelu; (2) unutardržavnu analizu u kojoj se analiziraju različiti dijelovi istog upravnog sustava, primjerice usporedba saveznih pokrajina u Saveznoj Republici Njemačkoj; (3) međudržavnu analizu, koja dva ili više upravna sustava odnosno njezina dijela koristi kao temelj usporedbe u dvije ili više različitih država; (4) interkulturalnu analizu koja se odnosi na međudržavnu analizu upravnih sustava, a u analizu uključuje države koje su dio različitih kulturoloških i civilizacijskih krugova; usporedba upravnih sustava Kine i Velike Britanije, te (5) poredbeno-povijesna metoda koja upravne sustave izučava u različitim vremenskim trenutcima. Usporedba upravnog sustava prije i poslije ujedinjenja Savezne Republike Njemačke 1990. primjer je poredbeno-povijesne metode. Komparativna analiza različitih razdoblja može ujedno biti međuinstitucionalna, unutardržavna, međudržavna i interkulturalna (Pruthi, 2005, str. 265). Međudržavna analiza primijenjena kroz poredbeno-povijesnu metodu najzastupljenija 
je u komparativnim istraživanjima javne uprave u razdoblju od 2009. do 2015. Opseg 70\% svih objavljenih komparativnih radova odnosi se na međudržavnu analizu.

\subsubsection{Geografski fokus objarljenib članaka}

Koje zemlje usporediti i koliko njih, pitanje je koje se nameće prilikom formuliranja komparativnog istraživanja javne uprave. Intenzitet i detaljnost istraživanja najveći su prilikom istraživanja samo jedne zemlje odnosno kod studije slučaja, a širenjem geografskog obuhvata intenzitet se smanjuje. Fokusom na samo jednu zemlju gubi se upravo esencijalni dio komparativnog istraživanja, mogućnost usporedbe, poredbe ili komparacije između upravne pojave u različitim zemljama, stoga studije slučaja i ne možemo smatrati komparativnima, no, ipak, studije slučaja imaju značajnu komparativnu vrijednost. Studije slučaja mogu se smatrati komparativnima ako se oslanjaju na neki model uprave ili upravnu teoriju (Lalić Novak, 2015, str. 22). S druge strane, ako je komparativno istraživanje geografski raspršeno i obuhvaća velik broj zemalja, ono je lišeno detalja, no zbog jake empirijske utemeljenosti nudi mogućnost izvođenja zaključaka o istraživanoj upravnoj pojavi (Lor, 2012, str. 11).

Studije slučaja, usporedba malog broja zemalja i usporedba velikog broja zemalja tri su moguća oblika komparativnog istraživanja javne uprave. Iako studije slučaja ne možemo smatrati komparativnima, one imaju komparativnu vrijednost sadržavaju li koncepte koji su primjenjivi i na druge zemlje. Studije slučaja korisne su u testiranju hipoteza i determiniranju uzročnoposljedičnih odnosa. Studije slučaja omogućavaju dubinski uvid u određenu upravnu pojavu ili određeni upravni koncept (Lor, 2012, str. 11).

Širenjem fokusa istraživanja suvremenih trendova u komparativnim istraživanjima javne uprave i na studije slučaja broj članaka doseže 53. Kategorija studija slučaja čini $75 \%$ svih radova obuhvaćenih analizom. $61 \%$ svih radova hrvatskih autora te $87 \%$ članaka stranih autora kategorizirani su kao studija slučaja. Iako u studijama slučaja komparativna istraživačka metoda nije primijenjena, takvi radovi imaju snažnu komparativnu vrijednost jer sadržavaju koncepte koji su primjenjivi kako u Hrvatskoj tako i u drugim zemljama.

Geografski fokus osam od 13 komparativnih radova usmjeren je na Njemačku, slijedi Francuska sa šest te Velika Britanija, Švedska i Poljska sa po pet komparativnih članaka. U primarnoj selekciji zemalja koje će činiti srž komparacije upravni stručnjaci odabiru upravne sustave i dijelove upravnih sustava velikih razvijenih demokratskih europskih zemlja zbog 
Tablica 1. Prikaz učestalosti pojavljivanja određene države u objavljenim člancima

\begin{tabular}{lcc}
\hline \multicolumn{1}{c}{ Država } & $\begin{array}{c}\text { Učestalost } \\
\text { pojavljivanja }\end{array}$ & $\begin{array}{c}\text { Postotak od } \\
\text { ukupnog broja } \\
\text { časopisa }\end{array}$ \\
\hline Slovenija & 14 & $26 \%$ \\
\hline Francuska & 12 & $23 \%$ \\
\hline Njemačka & 9 & $17 \%$ \\
\hline Mađarska, Srbija & 8 & $15 \%$ \\
\hline Danska, Grčka, Poljska, Velika Britanija & 7 & $13 \%$ \\
\hline Slovačka, Švedska & 6 & $11 \%$ \\
\hline $\begin{array}{l}\text { Austrija, Belgija, Bugarska, Finska, } \\
\text { Rumunjska }\end{array}$ & 5 & $9 \%$ \\
\hline Češka, Litva, Nizozemska & 4 & $8 \%$ \\
\hline
\end{tabular}

Izvor: Hrčak, portal znanstvenih časopisa Republike Hrvatske, autorova analiza.

relevantnosti i utjecajnosti njihovih upravnih sustava, zbog dostupnosti pouzdane literature i geografske bliskosti. Pribrajanjem studija slučaja »pravim« komparativnim člancima kristalizira se značajan istraživački trend. Fokus četvrtine radova u razdoblju od 2009. do 2015. usmjeren je na Sloveniju, isto koliko i na drugih devet zemalja, u kategoriji ostale zemlje, zajedno. Taj istraživački trend može se objasniti ne samo zajedničkim povijesnim putevima Slovenije i Hrvatske i sličnošću dvaju upravnih sustava već i dostupnošću istraživačkog materijala.

Najčešća tema koja zaokuplja autore usredotočene na Sloveniju jest lokalna samouprava, decentralizacija i javne službe, a autori sedam od ukupno devet članaka koji tematiziraju Sloveniju redoviti su ili izvanredni profesori/ce te docenti/ce ili asistenti/ce iz Slovenije, odnosno pripadaju skupini stranih autora. $15 \%$ svih objavljenih studija slučaja tematski obuhvaća reformu javnog sektora i lokalnu samoupravu u Srbiji. Pretpostavka je da su autori najviše okrenuti upravo susjednim zemljama iz već navedenih razloga, ali i zbog odsustva jezične barijere. Lokalna samouprava i decentralizacija u Francuskoj pokriva svaki osmi članak u ovom periodu. Zastupljenost kategorije ostalih zemalja, Bosne i Hercegovine, Poljske, Makedonije, Belgije, Slovačke, Rumunjske, Ujedinjenog Kraljevstva, Njemačke i Estonije jest minimalna. U kategoriji studija slučaja primjetan je snažan eurocentristički pristup i odsustvo interkontinentalne i interkulturalne orijentacije. 
Grafikon 1. Prikaz zastuplienosti pojedinih država u kategoriji »studije slučaja«

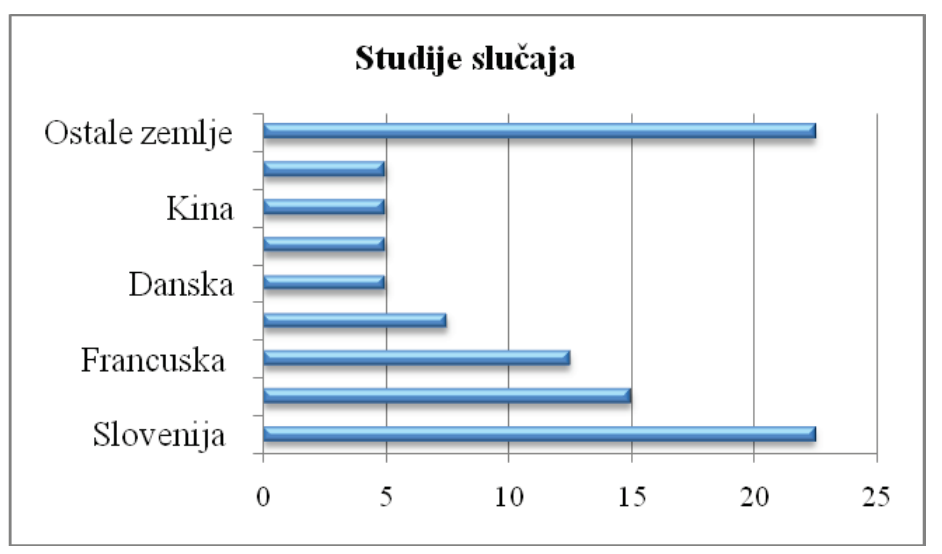

Izvor: Hrčak, portal znanstvenih časopisa Republike Hrvatske, autorova analiza.

Pri uspoređivanju velikog broja zemalja bogata i dubinska analiza problematike nije potrebna pa su kvantitativne istraživačke metode najzastupljenije. Razlozi se mogu svesti i na one praktične prirode: poteškoće u prikupljanju i analizi velike količine podataka za velik broj zemalja. U takvim istraživanjima odabir zemalja najčešće će biti slučajan. Države mogu biti grupirane prema geografskoj bliskosti, zajedničkom povijesnom nasljeđu ili civilizacijskom krugu kojemu pripadaju, a takva selekcija omogućuje mjerljivost i valorizaciju uspoređenih obilježja. U hrvatskim znanstvenim časopisima od 2009. do 2015. objavljeno je pet članaka u kojima se autor referira na 10 ili više zemalja. Neki od načina klasifikacije zemlja u tim člancima jesu: razvijene zemlje naspram tranzicijskih zemalja ili europske nasuprot anglosaksonske skupine zemalja. Dostupnost i pouzdanost podataka najčešće određuje koje će države u takvim radovima biti uspoređene.

$\mathrm{Na}$ kontinuumu između studije slučaja i velikog broja zemalja nalazi se usporedba malog broja zemalja ili nekoliko njih, no relevantnost metodološkog pristupa ipak ima prednost pred samim brojem uspoređenih država. Arend Lijphart upravo usporedbu malog broja država naziva komparativnom metodom (Lor, 2012, str. 14). Kritično pitanje u uspoređivanju malog broja zemalja jesti i koje zemlje odabrati. U ovom slučaju zemlje se ne odabiru nasumično, već se pomno selektiraju prema samoj svrsi istraživanja. Istraživanje može biti temeljeno na dizajnu »najsličnijih država« ili dizajnu »najrazličitijih država«, a odabir ne bi trebao pasti na 
jedinice usporedbe koje su toliko različite da ne postoji gotovo niti jedna dodirna točka, primjerice usporedba Andore i Kine. Također je nepotrebna usporedba između jedinica komparacije koje su gotovo identične (Lor, 2012, str. 14). Oba navedena temeljna dizajna komparativnog istraživanja primijenjena su u člancima objavljenima u hrvatskim znanstvenim časopisima: usporedba Njemačke i Francuske pojavljuje se kao primjer dizajna »najrazličitijih zemalja«, a usporedba Australije, Novoga Zelanda i Velike Britanije kao primjer dizajna »najsličnijih zemalja«. Osam od 13 komparativnih članaka sadržava komparaciju malog broja zemalja ili nekoliko njih. Najzastupljenija zemlja u komparativnim radovima malog broja zemalja je Njemačka.

Kategorija komparativnih članaka u kojima se određena upravna pojava razmatra u najmanje dvije države odnosno jedinice analize podzastupljena je u odnosu na ukupni broj objavljenih radova. Primjerice, u časopisu Hrvatska i komparativna javna uprava pojavnost komparativnih znanstvenih radova u periodu od 2009. do 2015. iznosi 0,43 komparativna rada po jediničnom broju časopisa. Međutim, objavom značajnog broja studija slučaja koje sadržavaju upravne koncepte primjenjive i u drugim zemljama časopis Hrvatska i komparativna javna uprava značajno doprinosi razvoju i profilaciji discipline komparativne javne uprave u Hrvatskoj. Iako je dizajn studije slučaja dominantna forma izučavanja javne uprave, komparativna vrijednost objavljenih radova je neupitna.

Komparativno promišljanje upravnih fenomena treba postati esencijalni dio upravnih istraživanja u današnjoj umreženoj i povezanoj globalnoj okolini. Komparativna perspektiva omogućuje neposredno prepoznavanje pozitivnih i negativnih posljedica upravnih reformi i pridonosi razumijevanju funkcioniranja upravnih fenomena u različitim društvenim, političkim, upravnim i pravnim okolišima. Stoga znanstvenike i studente treba poticati da promišljaju i istražuju komparativno kako bi komparativna javna uprava, upravna znanost i javna uprava općenito mogla višestruko profitirati od navedenih benefita.

\subsection{Tematska struktura članaka}

Temeljem analize članaka objavljenih u razdoblju od 2009. do 2015. u časopisima Hrvatska i komparativna javna uprava i Anali Hrvatskog politološkog društva autor zaključuje da je najzastupljenija tema lokalna samouprava. Tri četvrtine objavljenih komparativnih članaka tematski obrađuje lokalnu samoupravu. Širenjem fokusa i na studije slučaja tematika 
lokalne samouprave još je i snažnije prisutna. 57\% članaka objavljenih u analiziranom periodu odnosi se na lokalnu samoupravu, a gotovo polovina svih članaka s navedenom tematikom objavljena je 2012. S obzirom na to da se u radovima reflektiraju upravne, političke, pravne, društvene i druge prilike $\mathrm{u}$ istraživanom upravnom sustavu, potpuno je jasan fokus autora na lokalnu samoupravu. Lokalna samouprava i reforma teritorijalnog ustrojstva još su od osamostaljenja Republike Hrvatske u stalnom fokusu građana, političara te stručne i znanstvene javnosti. S obzirom na koncepcijsku srodnost temu lokalna samouprava i decentralizacija možemo promatrati objedinjeno, tada se čak $80 \%$ članaka odnosi na navedene teme. Tako velik postotak odaje veliko značenje i stalnu aktualnost koju lokalna samouprava i decentralizacija imaju u Hrvatskoj, a pokazuje značajan i snažan trend u komparativnim istraživanjima javne uprave.

Grafikon 2. Prikaz tematske strukture objavljenih članaka

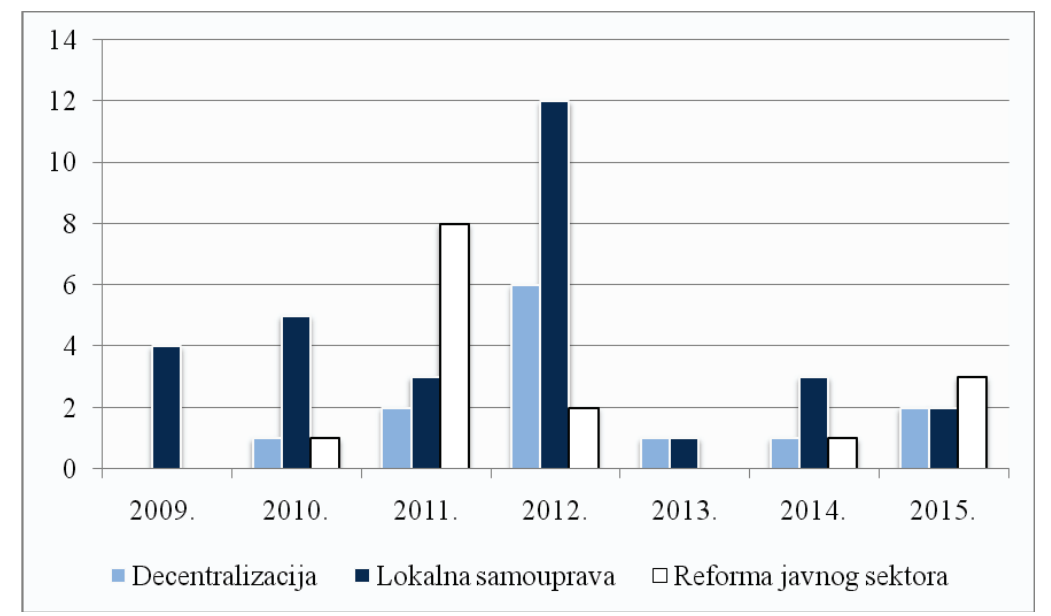

Izvor: Hrčak, portal znanstvenih časopisa Republike Hrvatske, autorova analiza.

Rezultati istraživanja zastupljenosti tema u znanstvenim časopisima o javnoj upravi u razdoblju od 1999. do 2009. pokazali su slične trendove. Tematsku strukturu trećine objavljenih radova čine teme lokalne i regionalne samouprave te decentralizacija, što tu skupinu tema čini najčešćom, druge dvije teme po zastupljenosti su službenici i europeizacija (Lopižić, 2013, str. 411-112). Orijentacija i interes znanstvene i stručne javnosti prema lokalnoj samoupravi i decentralizaciji su indikativni, te pokazuje relevantnost lokalne samouprave u demokratskoj državi. 


\subsection{Metodološki pristupi objavljenih članaka}

U komparativnim istraživanjima koriste se metode društvenih istraživanja: kvantitativne, kvalitativne i mješovite metode. Posljednjih godina kruta podjela na kvantitativne i kvalitativne metode sve se više rastače, a istraživanjima se pristupa sa svojevrsnim metodološkim pluralizmom, u društvenim znanostima općenito, a posebice u komparativnim istraživanjima. Tako se naizmjence mogu primijeniti kvalitativne i kvantitativne metode ili podjednako i jedne i druge ili se koriste obje, ali jedna metoda uvijek prevladava (Lor, 2012, str. 6-7). Za potrebe ovoga rada, mješovite metode istraživanja neće se analizirati, već će se razdioba temeljiti na kvalitativnim i kvantitativnim metodološkim pristupima.

Metodološki izbor ovisit će o svrsi samog istraživanja. Primjenom kvantitativnih istraživačkih metoda dobivamo numerički opisanu pojavu, dok je primjenom kvalitativnih metoda analiziranu upravnu ili drugu pojavu moguće dublje opisati i razumjeti. Neke od metoda kvantitativnog istraživanja su: ankete, eksperimenti i kvazieksperimenti, promatranje, analiza sadržaja i nenametljiva istraživanja. Metode kvalitativnog istraživanja su intervjui, fokus grupe i promatranje sa sudjelovanjem. Obje skupine metoda usmjerene su na zaključivanje iz već dostupnih podataka (Lalić Novak, 2015, str. 17-19).

Istraživač koji primjenjuje kvantitativne istraživačke metode može određeni pojam, poput korupcije, lokalne samouprave ili službeničkog sustava, istražiti bez napuštanja svog radnog stola. Primjerice, postojanje odnosa između veličine lokalnih jedinica i participacije građana u lokalnoj demokraciji je hipoteza koju istraživač provjerava kvantitativnim metodama; statističkim podacima, anketama ili analizom regulative. Kvalitativna komparativna istraživanja u samom početku ne sadržavaju varijable ili hipoteze, već se određena upravna pojava dubinski analizira te vremenski i prostorno kontekstualizira. Primjenom kvalitativnih metoda participacija građana u lokalnoj demokraciji analizirala bi se intervjuima ili promatranjem sa sudjelovanjem koje uključuje prisutnost istraživača u situaciji koju istražuje, no ne nužno (Lor, 2012, str. 9).

Kvantitativne istraživačke metode zastupljene su u osam od 13 komparativnih radova, a kvalitativne u pet analiziranih komparativnih članaka. Proširimo li fokus i na studije slučaja, kvalitativne metode postaju dominantni metodološki izbor, sa 68 postotnom zastupljenošću. Kvalitativne metode omogućuju dubinsku analizu i razumijevanje promatranog upravnog pojma ili upravne pojave te se one najčešće izvode prilikom uspoređivanja malog broja zemalja ili studija slučaja. $83 \%$ svih članaka u kojima su 
kvalitativne metode istraživanja primijenjene odnosi se na studije slučaja, a preostalih $17 \%$ na komparaciju dviju ili triju država.

Za opisivanje i promatranje određene upravne pojave u velikom broju zemalja kvantitativna istraživanja svojevrsni su metodološki temelj. Analize statističkih podataka, ankete i analiza sadržaja najčešće su kvantitativne metode koje omogućuju izvođenje zaključaka o određenoj upravnoj pojavi promatranjem faktora u velikom broju slučajeva. Primjena kvalitativnih metoda u analizi koja uključuje velik broj zemalja nije uobičajena zbog poteškoća u prikupljanju i dubinskim analizama velike količine podataka za velik broj zemalja. Pouzdanost velikog spektra informacija za velik broj zemalja također predstavlja jedan od problema (Lor, 2012, str. 12).

Kvantitativne metode istraživanja primijenjene su u $32 \%$ objavljenih komparativnih članaka i studija slučaja u periodu od 2009. do 2015., a u svakom drugom članku autor testira hipotezu, odnosno u četiri od pet članaka sa 10 ili više promatranih država. To potvrđuje i svojevrsno pravilo da komparacije velikog broja zemalja sadržavaju testiranje hipoteza (Lor, 2012, str. 12).

Izvor podataka u istraživanjima komparativne javne uprave u najvećem se broju članaka podudara. Autori najčešće ponovo analiziraju i interpretiraju postojeću literaturu i provedena istraživanja, službene dokumente, statističke podatke, pravne propise i relevantne web stranice.

\subsubsection{Vrste objavljenih članaka i vrste istraživanja}

Istraživanje suvremenih trendova u komparativnim istraživanjima javne uprave usmjereno je na recenzirane radove koji mogu biti kategorizirati kao: izvorni znanstveni rad, pregledni znanstveni rad, prethodno znanstveno priopćenje i stručni rad. $U$ analiziranom periodu više od $50 \%$ komparativnih radova kategorizirani su kao izvorni znanstveni rad, dok kategoriji pregledni znanstveni rad i stručni rad pripadaju četiri odnosno dva od 13 usporednih radova. Pribrajanjem studija slučaja ovoj analizi pregledni znanstveni rad postaje dominantna kategorija s 50\% svih znanstvenih članaka, dok kategoriji izvorni znanstveni rad pripada četvrtina radova. Stručni radovi i kategorija prethodno znanstveno priopćenje zastupljeni su u $15 \%$ svih objavljenih radova.

S obzirom na primjenu rezultata istraživanja razlikuju se dvije skupine istraživanja: izviđajna odnosno eksplorativna i zaključna ili konkluzivna. Kategorija zaključnih istraživanja dijeli se na dvije podskupine: opisna ili deskriptivna istraživanja i uzročna ili kauzalna istraživanja. Uvid u pro- 
blem ili postizanje boljeg razumijevanja određene pojave, što naposljetku pomaže u rješavanju problema, omogućuje izviđajno istraživanje. Vrsta istraživanja kojoj je svrha opis određene pojave ili utvrđivanje njezine učestalosti jest opisno istraživanje, a utvrđivanje odnosa uzroka i posljedica među faktorima svrha je uzročnog odnosno kauzalnog istraživanja. (Bhattacherjee, 2012, str. 6)

U više od polovine svih komparativnih radova zastupljeno je deskriptivno istraživanje. Primjena deskriptivnog istraživanja još je i izraženija pribrojimo li analizi studije slučaja. Opisno istraživanje zastupljeno je u $75 \%$ svih objavljenih članaka. Eksploratorno istraživanje primijenjeno je u 13\% objavljenih članaka, a kauzalno u 2 od ukupno 53 članka obuhvaćena ovim istraživanjem.

\section{Zaključak}

Esencijalni dio upravne znanosti u 21. stoljeću jest mogućnost komparacije, usporedbe odnosno poredbe različitih upravnih koncepata, upravnih sustava i njihovih dijelova u različitim zemljama ili drugim jedinicama usporedbe; regijama, pokrajinama ili gradovima, a potaknuta dostupnošću podataka o različitim zemljama svijeta. Vremenski presjek i usporedba prošlog i sadašnjeg upravnog stanja, može pridonijeti toliko potrebnom deficitu malformacija upravnog sustava u budućnosti. Budućnost, koja donosi još veći stupanj globalizacije i umreženosti, još veću dostupnost informacija o upravnim sustavima različitih zemalja, tražit će i ekstenzivniju primjenu komparativne metode u upravnoj znanosti, jer, kako je Ferrel Heady naglasio, istinske upravne znanosti nema bez komparativnog proučavanja javne uprave.

Istraživanje suvremenih trendova u usporednim istraživanjima javne uprave, odnosno ovaj rad, autor je otpočeo s hipotezom da hrvatski znanstveni časopisi imaju značajan komparativni segment. Istraživanje je provedeno metodom proučavanja znanstvenih radova u časopisima objavljenih u periodu od 2009. do 2015. godine., a pokazuje da je kategorija studija slučaja dominantna forma u proučavanju javne uprave u tom razdoblju. Iako se toj formi ne može pripisati komparativni predznak, ona ipak ima značajnu komparativnu vrijednost. Dubinska analiza 151 časopisa s područja društvenih znanosti rezultirala je sa sveukupno 13 komparativnih radova koji tematiziraju javnu upravu, a koji su objavljeni u razdoblju od 2009. do 2015. godine, te 40 studija slučaja. Časopis Hrvatska i komparativna 
javna uprava, jedini specijalizirani časopis za područje komparativne javne uprave u Hrvatskoj, sadržava i najviše komparativnih radova. Učestalost komparativnih znanstvenih radova u periodu od 2009. do 2015. godine iznosi 0,43 komparativna rada po jediničnom broju časopisa. Međutim, objavom značajnog broja studija slučajeva koje sadržavaju upravne koncepte primjenjive i u drugim zemljama časopis Hrvatska i komparativna javna uprava značajno pridonosi razvoju i profilaciji discipline komparativne javne uprave u Hrvatskoj. Iako studije slučaja imaju značajnu i neupitnu komparativnu vrijednost, koja je višestruko naglašena, komparativni znanstveni radovi omogućuju neposredno prepoznavanje, uspoređivanje i kontekstualiziranje najboljih praksi i upravnih koncepata, stoga znanstvenu i stručnu javnost treba više poticati i ohrabrivati da promišljaju i istražuju komparativno.

U geografskom fokusu 8 od 13 komparativnih članaka je Njemačka, a slijedi je Francuska sa 6 te Velika Britanija, Švedska i Poljska sa po 5 usporednih radova. Upravni sustavi velikih europskih demokratskih zemalja sa snažnim i dugim upravnim tradicijama učestali su odabir usporednih radova kako zbog relevantnosti i utjecajnosti tih upravnih sustava tako i zbog dostupnosti pouzdanih izvora literature i geografske bliskosti. Najzastupljenija tematska cjelina u analiziranom razdoblju je lokalna samouprava, a upravni stručnjaci u komparativnim analizama najviše su skloni središnjoj, mezzo, razini analize. S obzirom na to da tekući radovi predstavljaju svojevrsno ogledalo prilika u upravnoj znanosti i javnoj upravi općenito, aktualnost lokalne samouprave ne čudi. Zbog financijske neodrživosti, neučinkovitosti i upitne svrsishodnosti pojedinih lokalnih samoupravnih jedinica, lokalna samouprava i reforma teritorijalnog ustrojstva još su od osamostaljenja Republike Hrvatske u stalnom fokusu građana, političara te stručne i znanstvene javnosti. Kvantitativne istraživačke metode zastupljene su u 60\% usporednih članaka, a kvalitativne u 40\% analiziranih komparativnih članaka. Proširivanjem fokusa i na studije slučaja kvalitativne metode postaju dominantni metodološki izbor, sa 68-postotnom zastupljenošću. Autori najčešće ponovo analiziraju i interpretiraju postojeću literaturu i provedena istraživanja, službene dokumente, statističke podatke, pravne propise i relevantne web stranice. Istraživanje kojem je svrha opis ili utvrđivanje učestalosti određene upravne pojave najzastupljenija je vrsta istraživanja, a zastupljeno je u više od polovine svih komparativnih radova.

U objavljenim člancima prisutan je snažan eurocentričan pristup i gotovo potpuno odsustvo interkulturalnog i interkontinentalnog, odnosno globalnog, pristupa istraživanju javne uprave. Komparativni segment objavljenih članaka nedostatan je, međutim iznimno komparativno vrijedan. 
Temeljem rezultata istraživanja suvremenih trendova u komparativnim istraživanjima javne uprave u Hrvatskoj od 2009. do 2015. godine autor djelomično odbacuje početnu hipotezu te predlaže zaokret u promišljanju upravnih fenomena; od eurocentrizma prema globalnom pristupu i od studije slučaja prema komparativnim istraživanjima. Komparativna perspektiva potrebna je za potpunije i neposredno razumijevanje svih upravnih fenomena, ne samo lokalne samouprave. Na etiku javne službe, novi javni menadžment, upravljanje, javne financije i odgovornost za rezultate u upravi potreban je širi pogled od striktno regionalnog i europskog. Ekstenzivnija primjena komparativne metode u znanstvenim radovima nužna je također kako za daljnji razvoj same discipline komparativne javne uprave u Hrvatskoj tako i za uspostavu značajnijeg komparativnog segmenta u hrvatskim znanstvenim časopisima, čime jača njihova znanstvena kvaliteta i relevantnost. Komparativni segment hrvatskih znanstvenih časopisa, posebice časopisa specijaliziranih za javnu upravu, može biti osnažen i usvajanjem preporuka iznesenim u radu $A$ New Look at Comparative Public Administration: Trends in Research and an Agenda for the future autora Jasona Machadoa i Christine Martell. Širi spektar upravnih tema potrebno je promišljati i istraživati komparativno. Nužan je značajan iskorak u geografskom fokusu komparativnih istraživanja: od striktno europskog pristupa prema globalnom. Međutim, najznačajniji pomak potreban je u samom dizajnu komparativnih istraživanja; od studija slučaja prema usporedbi dviju ili više jedinica analize. Mogućnost analize dvaju ili više upravnih sustava bez prenošenja negativnih implikacija u vlastiti upravni sustav najpoželjnije je svojstvo komparativne javne uprave u visokorizičnom i nestabilnom političkom, društvenom i ekonomskom okolišu 21. stoljeća.

\section{Literatura}

Basu, R. (2009). Public Administration: Concepts And Theories, Fifth Revised and Enlarged Edition. New Delhi, India: Sterling Publishers Private Limited

Bhattacherjee, A. (2012). Social Science Research: Principles, Methods, and Practices. Tampa, USA: Createspace Independent Pub.

Chandler, J. A. (2014). Comparative Public Administration, Second edition. New York, USA: Routledge

Heady, F. (2006). Comparison in the Study of Public Administration. U Otenyo E. E. \& Lind N. S. (eds.) Comparative Public Administration: The Essential Readings. Research in Public Analysis and Management, Volume 15. (str. 67121). Amsterdam, Netherlands: Elsevier Ltd. 
Lalić Novak, G. (2015). Komparativna metoda u proučavanju javne uprave: potencijali i problemi. Hrvatska $i$ komparativna javna uprava - Croatian and Comparative Public Administration, 15(1), 9-31.

Lopižić, I. (2013). Usporedba zastupljenosti tema u znanstvenim časopisima o javnoj uprave. Hrvatska $i$ komparativna javna uprava - Croatian and Comparative Public Administration, 13(2), 399-431.

Lor, P. J. (2012). International and Comparative Librarianship, A Thematic Approach. Global Studies in Libraries and Information. Berlin, Germany: K.G. Saur Verlag GmbH

Machado J. \& Martell C. (2011). A New Look at Comparative Public Administration: Trends in Research and an Agenda for the Future. Public Administration Review 11(71, 6), 821-830. doi: 10.1111/j.1540-6210.2011.02432.x.

Otenyo, E. \& Lind N. (2006). Comparative Public Administration: Growth, Method, and Ecology. U Otenyo, E. \& Lind N. (ur.), Comparative Public Administration: The Essential Readings. Research in Public Analysis and Management, Volume 15. (str. 1-7). Amsterdam, Netherlands: Elsevier Ltd.

Pruthi, R. K. (2005). Administrative Management and Planning. New Delhi, India: Discover Publishing House

Rathod, P. B. (2007). Comparative Public Administration. Jaipur, India: ABD Publishers.

\section{Prilog 1}

1. Breuillard, M. (2012). From Paris to Greater Paris: An Old Project, a New Approach. Hrvatska $i$ komparativna javna uprava- Croatian and Comparative Public Administration, 12(1), 41-69.

2. Crnković, M. (2010). Lokalna samouprava u Poljskoj. Hrvatska i komparativna javna uprava- Croatian and Comparative Public Administration, 10(4), 10591080 .

3. De Ceuninck, K. (2011). Flanders Heading Towards Its Own State Reform. Hrvatska i komparativna javna uprava-Croatian and Comparative Public Administration, 11(4), 1017-1039.

4. Delaneuville, F. (2012). Special Legal Status of Bratislava as a European Capital City. Hrvatska $i$ komparativna javna uprava-Croatian and Comparative Public Administration, 12(1), 71-84.

5. Dong L. \& Liu X. (2015). Public Service Reform in China. Hrvatska $i$ komparativna jarna uprava-Croatian and Comparative Public Administration, 15(3), 569-592.

6. Dong L., Cui Q. \& Christensen T. (2015). Local Public Services Provision in China - An Institutional Analysis. Hrvatska i komparativna javna uprava-Croatian and Comparative Public Administration, 15(3), 618-643.

7. Đorđević S. (2012). Decentralizacija i jačanje kapaciteta lokalnih vlasti u Srbiji. Anali Hrvatskog politološkog društva- Croatian and Comparative Public Administration, 12(8), 179-202. 
8. Đorđević S. (2011). Public Service Reform in Serbia. Hrvatska i komparativna jarna uprava- Croatian and Comparative Public Administration, 11(4), 925-946.

9. Dubajić D. (2011). Regionalizacija Slovenije - napori za uspostavom srednje razine vlasti. Hrvatska $i$ komparativna javna uprava-Croatian and Comparative Public Administration, 11(1), 9-42.

10. Dubajić D. (2010). Lokalna samouprava u Sloveniji. Hrvatska i komparativna javna uprava- Croatian and Comparative Public Administration, 10(2), 465-487

11. Đurman P. (2015). Javna uprava i politički sustav Ujedinjenog Kraljevstva: između tradicije i reformi. Hrvatska $i$ komparativna javna uprava-Croatian and Comparative Public Administration, 15(1), 69-102.

12. Đurman P. \& Musa A. (2014). Problem koordinacije u javnoj upravi: natrag prema hijerarhiji? Anali Hrvatskog politološkog društva- Croatian and Comparative Public Administration, 14(1), 111-138.

13. Džinić J. (2015). Javna uprava i politički sustav u Estoniji: u potrazi za ravnotežom između menadžerskih reformi i dobrog upravljanja. Hrvatska $i$ komparativna jarna uprava-Croatian and Comparative Public Administration, 15(1), 175-208.

14. Džinić J. (2011). Public Administration Reform in Serbia. Hrvatska $i$ komparativna javna uprava-Croatian and Comparative Public Administration, 11(4), 1075-1105.

15. Guérard S. (2012). The Status of French »New Communes«. Hrvatska i komparativna javna uprava- Croatian and Comparative Public Administration, 12(1), 115-128.

16. Haček M. \& Bačlija I. (2014). Can Small Localities Perform? Trends in Administrative Capacity in Slovenian Municipalities. Hrvatska i komparativna javna uprava- Croatian and Comparative Public Administration, 14(1), 85-104.

17. Haček M. \& Grabner A. (2013). Local Sub-Decentralization and Sub-Municipal Divisions in Slovenia. Hrvatska $i$ komparativna javna uprava- Croatian and Comparative Public Administration, 13(1), 213-230.

18. Halligan J. (2012). Changing Approaches to Public Sector Reform in an Anglophone Country: The Australian Case in a Comparative Perspective. Hrvatska $i$ komparativna javna uprava- Croatian and Comparative Public Administration, 12(4), 983-1001.

19. Herak V. (2011). Madridski kriterij za pristupanje Europskoj uniji. Hrvatska $i$ komparativna javna uprava- Croatian and Comparative Public Administration, 11(3), 793-816.

20. Ivanišević S. (2009). Stupnjevanje lokalnih samoupravnih jedinica. Hrvatska $i$ komparativna javna uprava- Croatian and Comparative Public Administration, 9(3), 669-722.

21. Koprić I. (2012). Consolidation, Fragmentation, and Special Statuses of Local Authorities in Europe. Hrvatska $i$ komparativna javna uprava-Croatian and Comparative Public Administration, 12(4), 1175-1196.

22. Koprić I. (2009). Lokalna samouprava i lokalni službenički sustavi u Austriji i Finskoj. Hrvatska i komparativna javna uprava-Croatian and Comparative Public Administration, 9(3), 661-668. 
23. Kovač P. (2011). The Public Administration Reform Agenda in Slovenia Two Decades of Challenges and Results. Hrvatska $i$ komparativna javna uprava- Croatian and Comparative Public Administration, 11(3), 627-650.

24. Kovačić M. (2009). Reforma lokalne samouprave u Danskoj 2007. godine. Hrvatska i komparativna javna uprava-Croatian and Comparative Public Administration, 9(4), 977-988.

25. Kuhlmann S. (2011). Decentralisation in France: The „Jacobin” State Stuck between Continuity and Transformation. Hrvatska $i$ komparativna javna uprava- Croatian and Comparative Public Administration, 11(2), 311-336.

26. Lazin F. (2014). Local Government Reforms in Eastern Europe after the Collapse of the Soviet Union: Some Observations. Hrvatska $i$ komparativna javna uprava- Croatian and Comparative Public Administration, 14(1), 59-84.

27. Lilić S. (2011). Strategy of Administrative Reform in Serbia in the Context of European Integration. Hrvatska $i$ komparativna javna uprava- Croatian and Comparative Public Administration, 11(4), 1107-1122.

28. Lopižić I. (2015). Javna uprava i politički sustav u Francuskoj: središnja uloga države, uprave i prava. Hrvatska $i$ komparativna javna uprava- Croatian and Comparative Public Administration, 15(1), 103-140.

29. Manojlović R. (2015). Javna uprava i politički sustav Savezne Republike Njemačke: modernizacija kroz očuvanje tradicije. Hrvatska $i$ komparativna javna uprava- Croatian and Comparative Public Administration, 15(1), 141-174.

30. Manojlović R. (2011). Public Sector Reforms in Greece: Uncertain Outcome of 2010 Reforms. Hrvatska $i$ komparativna javna uprava- Croatian and Comparative Public Administration, 11(2), 337-377.

31. Manojlović R. (2010). Danski model novog javnog menadžmenta - može li poslužiti kao uzor Hrvatskoj. Hrvatska i komparatirna javna uprava- Croatian and Comparative Public Administration, 10(4), 961-996.

32. Manojlović R. (2009). Lokalna samouprava u Grčkoj. Hrvatska i komparativna javna uprava- Croatian and Comparative Public Administration, 9(4), 977-988.

33. Marčetić G. (2015). Komparativni službenički sustavi. Hrvatska i komparativna jarna uprava- Croatian and Comparative Public Administration, 15(1), 33-68.

34. Marčetić G. \& Giljević T. (2010). Lokalna samouprava u Njemačkoj i Francuskoj. Hrvatska i komparativna javna uprava-Croatian and Comparative Public Administration, 10(1), 67-78.

35. Mikulić S. (2009). Uloga upravljanja ljudskim potencijalima u procesu decentralizacije. Hrvatska $i$ komparativna javna uprava- Croatian and Comparative Public Administration, 9(4), 1091-1126.

36. Milosavljević B. (2012). Reforma lokalne samouprave u Srbiji. Hrvatska i komparativna javna uprava-Croatian and Comparative Public Administration, 12(3), 749-768.

37. Mujakić M. (2010). Lokalna samouprava u Federaciji Bosne i Hercegovine koncept, nadležnosti i organi. Hrvatska $i$ komparativna javna uprava-Croatian and Comparative Public Administration, 10(4), 1045-1058. 
38. Pavić Ž. (2010). Veličina lokalnih jedinica - europske tendencije i hrvatske nedoumice. Hrvatska $i$ komparativna javna uprava-Croatian and Comparative Public Administration, 10(1), 81-131.

39. Pavlovska-Daneva A. (2011). The European Administrative Space as a Challenge for Public Administration Reform in the Republic of Macedonia. Hrvatska $i$ komparativna javna uprava- Croatian and Comparative Public Administration, 11(1), 127-146.

40. Pevcin P. (2012). Local Government in Slovenia: Structure, Size, and Expenditures. Hrvatska $i$ komparativna javna uprava-Croatian and Comparative Public Administration, 12(3), 705-724.

41. Pevcin P. \& Rakar I. (2015). Local Public Services in Slovenia - Legal, Organisational, Economic and Financial Aspects. Hrvatska $i$ komparativna javna uprava- Croatian and Comparative Public Administration, 15(3), 697-714.

42. Protiêre G. (2012). The Status of Metropolises in France. Hrvatska i komparativna javna uprava- Croatian and Comparative Public Administration, 12(1), 129-148.

43. Rodica Staiculescu A. (2012). Special Status of Bucharest. Hrvatska $i$ komparativna javna uprava-Croatian and Comparative Public Administration, 12(3), 695-704.

44. Seidel T. \& Vakkuri T. (2015). Institutional Change of Quasi-Market Arrangements in Local Public Transportation - Comparative Observations from Germany and Finland. Hrvatska $i$ komparativna javna uprava-Croatian and Comparative Public Administration, 15(3), 595-615.

45. Sencur M. (2012). Lokalna samouprava u Sloveniji. Hrvatska $i$ komparativna javna uprava- Croatian and Comparative Public Administration, 12(3), 725-748.

46. Škarica M. (2015). Javna uprava i politički sustav u Albaniji: upravne reforme u nestabilnom političkom okruženju. Hrvatska $i$ komparativna javna upravaCroatian and Comparative Public Administration, 15(1), 209-242.

47. Škarica M. (2012). Public Administration Reforms in a Fragile Institutional Framework: The Case of Albania. Hrvatska i komparativna javna uprava-Croatian and Comparative Public Administration, 12(2), 361-389.

48. Stančetić V. (2012). Decentralization as an Aspect of Governance Reform in Serbia. Hrvatska $i$ komparativna javna uprava-Croatian and Comparative Public Administration, 12(3), 769-786.

49. Szalai A. (2012). Special Legal Status of Villages in Hungary. Hrvatska $i$ komparativna javna uprava-Croatian and Comparative Public Administration, 12(1), 85-100.

50. Tábit R. (2012). Towns with County Status in Hungary. Hrvatska i komparativna jarna uprava- Croatian and Comparative Public Administration, 12(1), 101-114.

51. Temesi I. (2012). Special Status of Budapest, the Capital of Hungary. Hrvatska $i$ komparativna javna uprava- Croatian and Comparative Public Administration, 12(1), 5-39.

52. Vlaj S. (2012). The System of Local Self-Government in Slovenia with a Special Emphasis on the Status of the Capital City Ljubljana. Hrvatska $i$ komparativna javna uprava- Croatian and Comparative Public Administration, 12(3), 675-694. 
53. Wollmann H. (2011). Reorganizing Local Government: Between Territorial Consolidation and Two-tier Intermunicipality. Hrvatska $i$ komparativna javna uprava- Croatian and Comparative Public Administration, 11(3), 681-706.

\section{CONTEMPORARY PUBLIC ADMINISTRATION RESEARCH IN CROATIAN SCIENTIFIC JOURNALS FROM 2009 TO 2016}

\section{Summary}

This article presents the results of the content analysis of 151 scientific journals in the field of social sciences, published in Croatia from 2009 to 2015. Papers comparing public administration concepts in at least two foreign countries or local and regional units were included. Thirteen comparative articles and 40 case studies were identified and underwent extensive content analysis. The research encompassed the following issues: type of article, purpose of research, subjects of research, and countries studied. Following the content analysis, the data were summarised as follows. The most commonly compared countries are Germany (in eight papers out of thirteen) and France (in six comparative studies). If case studies are included, Slovenia is the most commonly studied country. Local self-government is the subject most frequently addressed in comparative public administration research during the period in question. Quantitative research methods are used in eight out of thirteen comparative studies. If case studies are included, qualitative methods are the dominant methodological choice: almost $70 \%$ of the authors employed qualitative research methods used in the social sciences in their comparative public administration research. The study bypothesised that there is a major comparative segment in Croatian scientific journals. The conclusion is that the extent of the comparative perspective and the use of comparative research methods in public administration articles is not sufficient, but is exceptionally comparatively valuable. A wider array of public administration topics needs to be studied comparatively. An intercultural and intercontinental perspective should be incorporated into public administration studies. Scholars and researchers of public administration should shift their focus from eurocentrism to globalism, and from case studies to comparative research. To achieve a better understanding of how public administration works in different social, economic, and legal settings, our way of thinking, exploring, and writing needs to become more comparative.

Keywords: comparative public administration, scientific journals, comparative research method, content analysis 
